\title{
Use of Pesticides in the Cocoa Industry and Their Impact on the Environment and the Food Chain
}

\author{
George Afrane ${ }^{1}$ and Augustine Ntiamoah ${ }^{2}$ \\ 1 University of Ghana, Department of Food Process Engineering, \\ ${ }^{2}$ Koforidua Polytechnic, Department of Energy Systems Engineering, \\ Ghana
}

\section{Introduction}

Cocoa, Theobroma cacao L., is a major cash crop cultivated in the tropical regions of West Africa, the Caribbean, South America and Asia. In West Africa, where over $70 \%$ of the world's cocoa is produced - with about $21 \%$ coming from Ghana - it is a significant component of the rural economy, as the industry is dominated by large numbers of smallholder peasant farmers who depend on the crop for their livelihood (Acquaah, 1999; Appiah, 2004). Like all living organisms, the cocoa plant can also be attacked by a wide range of pests and diseases. When this happens expected production targets are not met, and the economies of the producer nations are adversely affected. Preventive and curative measures are therefore necessary in the cocoa industry to maintain and even increase output (Akrofi and Baah, 2007).

While non-chemical means of managing pests and diseases in the industry are widely recommended for health and other reasons, the use of some amounts of chemicals in the form of fertilizers, insecticides and fungicides is unavoidable in the effective management of cocoa farms (Moy and Wessel, 2000; Opoku et al., 2007; Adjinah and Opoku, 2010). Their use is therefore expected to increase with time. Indeed in the twenty-year period from 19862006, the use of fertilizer world-wide increased by almost 250\% (UNEP, 1991). The same trend applies to pesticides, although they are more difficult to monitor partly because of the secrecy that goes with the continued production and use of banned substances. The trends suggest quite clearly however, that much of the increase in world food production can be attributed to the response of crops to increased use of fertilizers and pesticides (UNEP, 1991). Fortunately, there has always been a clear appreciation of the potential deleterious effects of the chemicals used in the cocoa industry since the $60 \mathrm{~s}$, and standards have been set by FAO and WHO for acceptable levels of residues in the beans exported to other countries. The goal of maintaining high levels of agricultural productivity and profitability while reducing pesticides use presents a significant challenge. There are repeated cases of excessive levels of pesticide residues being found in agricultural produce and the safety of these products has become an issue of concern. Recently, changes in regulations in the European Union (EU), North America and Japan have called for a reflection on crop protection practices in cocoa and other commodity crops (ICCO, 2007). The quality of cocoa 
imported into the EU and elsewhere will be assessed based on traces of pesticides and other substances that have been used in the supply chain.

The cocoa bean has a high content of butter or fat which absorbs the active ingredients in insecticides. The acceptable levels of active ingredients in foods are determined by the committee on Pesticide Residue of $\mathrm{FAO} / \mathrm{WHO}$, known as the Codex Alimentarius Commission, CAC. Created in 1963 the CAC implements the Joint FAO/WHO Food Standards Programme which is aimed at protecting the health of consumers and ensuring fair trade practices in the international food trade (Moy and Wessel, 2000). The commission has set maximum levels of residue poisons in commodities going through the international market, including cocoa. If for any reason the residual levels in any commodity exceed the Codex levels, that particular commodity could be rejected by the importing country. Secondly, the accumulation of any chemicals in the cocoa fat may change the taste of the beans and eventually that of the chocolate made from them. This is known as tainting. It is therefore, the task of entomologists to ensure that recommended chemicals do not leave any residues, and that the dosage is the minimum that would give the optimum control under the agricultural conditions in the country.

In Ghana, significant gains have been made in the control of pests and diseases of the cocoa industry through the nationwide use of pesticides under government sponsorship and supervision. The growing global concerns about the effects of the increasing use of agricultural chemicals on farmers, consumers of agricultural produce and the ecology require a re-examination of the issues related to their application in the cocoa industry. This chapter examines the use and the impact of pesticides in cocoa production in Ghana - where data has been accumulated - as a representative country of the industry. The potential ecological impacts of chemicals in the cocoa industry are analyzed, using the modern tool of life-cycle assessment (Ntiamoah and Afrane, 2009). Life-cycle assessment, LCA, has gained such prominence in the environmental management discipline that the International Standards Organization has developed standards for its implementation (ISO 14040-14043, 1997-2000b). This particular analysis is based on primary farm-level data collected from a nationally representative sample of cocoa farmers, published data, results from research institutions, the Ghana Cocoa Board and other relevant sources.

\section{The Ghanaian cocoa industry in brief}

In Ghana, cocoa has played an important role in the economy of the country for over one century. Although the crop was believed to have been brought to the colonial Gold Coast as Ghana was then known - from Fernando Po, an island in the Gulf of Guinea, off the coast of Gabon, in 1879 and from Sao Tome in 1886, records show that in 1891, only twelve years after it first arrived here, cocoa was being exported as a cash crop (Acquaah, 1999, Adjinah and Opoku, 2010). From the 1910/1911 season, Ghana became the leading cocoa producer in the world, a position it held until 1977, when it was overtaken by the Ivory Coast. The country went from being the number one cocoa producer to a period in the early 80 s when, as a result of drought, bushfires, low producer prices, diseases and general economic malaise, Ghana fell to the twelfth position and produced less than 160,000 metric tonnes in the 1983/1984 season (Adjinah and Opoku, 2010).

Cocoa became attractive as a cash crop in Ghana because of the lower cost involved in its cultivation, compared to a popular crop like palm, as well as the favourable natural conditions that existed in the forest belts. Cocoa could be grown along with other crops and 
when soil conditions deteriorated the land could be left to the cocoa trees and other tracts tilled in the shifting-cultivation systems of farming (Acquaah, 1999). Because of the prominence that the crop had began to gain in the economy, even before World War II, government was seriously alarmed when the swollen shoot disease was discovered in 1936. In the process of combating this disease, a permanent research center was established at Tafo, in the Eastern Region, and product quality inspectorate, grading of beans, extension services and proper engagement of farmers in the growth of the crop were initiated (Acquaah, 1999). Since then government has continued to offer technical assistance, financial incentives and inputs like fertilizer and pesticides to cocoa farmers.

Over the last decade, as a result of government intervention, cocoa production has picked up, reaching a peak of 740 thousand metric tonnes in the 2005/2006 season (Aryeetey et al, 2007). Constituting 7.3\% of the Gross Domestic Product of the country, it is second only to gold, which first overtook cocoa as the highest foreign exchange earner in 1992; a trend which still continues. Agriculture contributes about 35\% of Ghana's Gross Domestic Product (GDP) and $60 \%$ of total employment. The Cocoa Industry is the single largest contributor to agricultural GDP $(16.5 \%)$. It is estimated that about $65 \%$ of the country's agricultural workforce work either directly or indirectly in the cocoa industry. In Ghana cocoa is grown on small farms owned by individuals and families in the forest zones of Ashanti, Brong Ahafo, Western, Eastern and Volta regions. Thus the livelihood of about two million farmers and their dependants, mostly in the rural areas, depend directly on cocoa (Opoku et. al, 2006).

\subsection{Cocoa processing in Ghana}

Although serious attempts have been made to process them locally, the majority of cocoa beans produced in the country are still exported. Government put a policy in place to process at least $50 \%$ by the end of the last decade. The enabling conditions created in free zone enclaves, led to the attraction of private foreign processing companies and the expansion of state-owned facilities. According to data from International Cocoa Organization, ICCO, 200,000 metric tonnes of cocoa grindings were achieved in Ghana in the 2009/2010 season. Compared to the production figure given in Table 1 for the same season, this constitutes about $32 \%$ of the beans produced. This means the government's target for grindings was not achieved.

In spite of their peripheral role in the standard household menu - mainly as a dessert or snack, food products made from cocoa go through a long line of operations not normally found with other processed foods, as depicted in Figure 1 (Awua, 2002). Ripe cocoa pods are plucked from the trees and gathered together on clearings in the cocoa farms. After about ten days, all available hands, young and old, gather together to assist in the splitting of the pods and removal of the beans with their hands. (According to Owusu-Manu (1977), this could be a critical stage in the contamination process, with pesticides getting transferred from the workers to the wet beans.) The wet beans are collected together in a heap and covered with plantain leaves and plastic sheets for fermentation. After fermentation, the beans are dried in the sun on bamboo mats to a desired moisture content of around $7.5 \%$.

After dried cocoa beans have been received at the processing plant, they are inspected and thoroughly cleaned of all extraneous matter, such as sticks, stones, metal fragments, dust, loose shells, small fragments and clumps of cocoa beans. The cleaning process consists of a series of operations involving sieves, brushes, airlifts and magnetic separators to remove the 


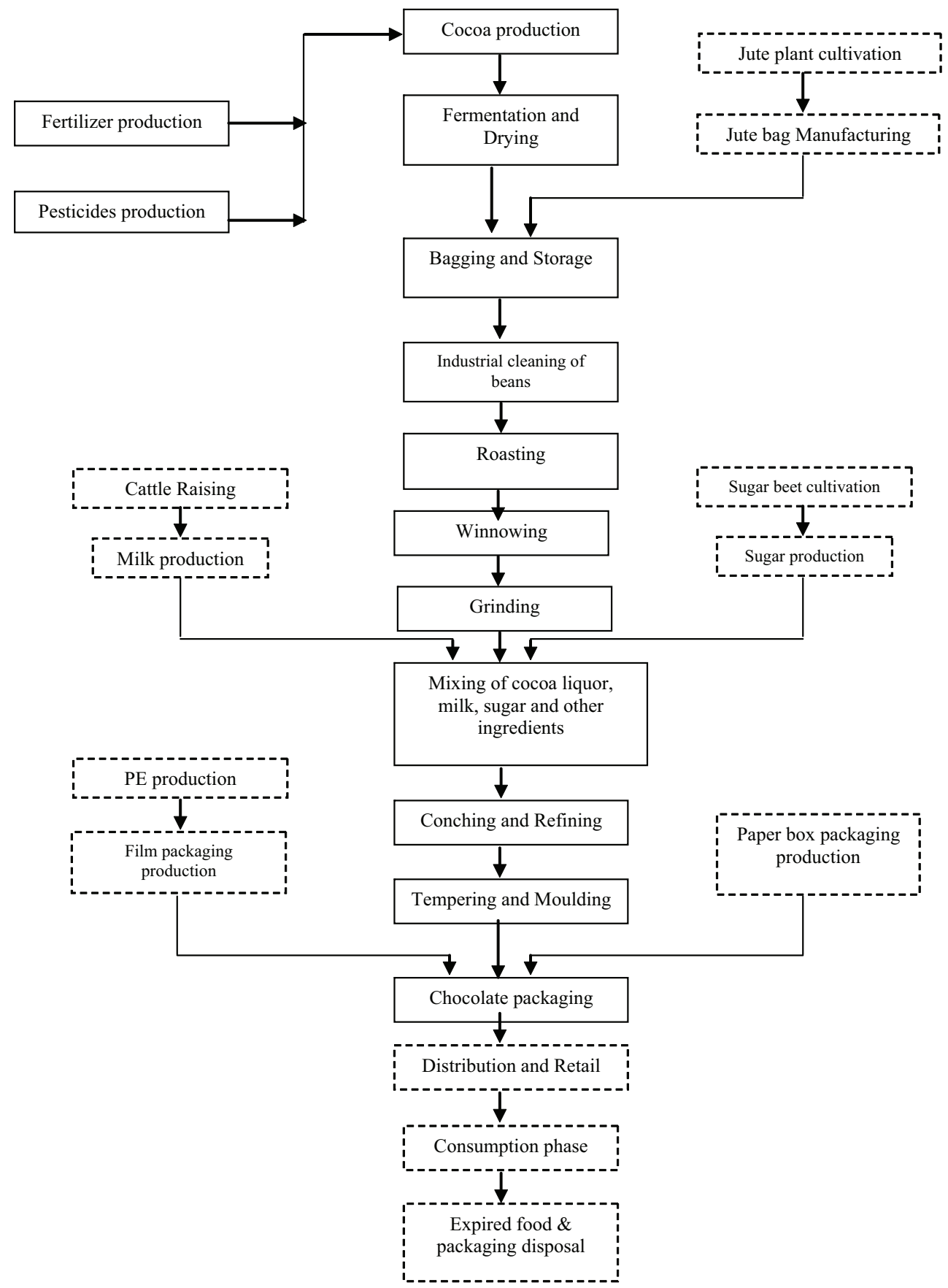

Fig. 1. Process Flowchart for Chocolate Production 
unwanted materials. The cleansed cocoa beans are roasted at temperatures between 90$170^{\circ} \mathrm{C}$, using a petroleum-based fuel or electricity. This process is needed to develop the chocolate flavour, reduce the moisture content further, and loosen the shells for subsequent removal. The nibs (cotyledons) become friable and generally darker in colour in the process. At the next stage, the shells are separated from the nibs in a process known as winnowing. Winnowing machines use a multi-layered sieve frame with meshes of different sizes, one above the other, with the largest mesh on top. The roasted and crushed beans are ground into a paste known as cocoa liquor or cocoa masse. The grinding process is achieved in two or three stages, using a combination of mills. The cocoa liquor obtained is heat-treated in storage tanks at temperatures of between $90-100^{\circ} \mathrm{C}$ for aging and microbial destruction.

The cocoa paste could be pressed in a hydraulic device to extract cocoa butter. The cake released after pressing is passed through kibbling machines, which break them into smaller pieces, and are packed into four-ply multi-walled paper sacks lined with polyethylene. These are ready for sale and shipment as kibbled cake. The cocoa butter, on the other hand, may be mixed with the other ingredients of chocolate, namely, butter, sugar, milk and emulsifiers. The chocolate mix is subjected to additional processes known as conching and tempering. Conching removes residual moisture, while tempering transforms the thick semi-liquid mix into a solid product through heat treatment. After this process the chocolate is poured into moulds of different shapes and then packaged for the market. Knowledge of the material and energy requirements of each of the processes as shown in figure 1 is necessary to perform the LCA analysis needed to determine the environments impacts.

\subsection{The place of cocoa in the food chain}

While the soporific effect of cocoa drinks is widely known, recent research activities have unearthed additional more important health benefits which have enhanced further the attractiveness of cocoa products generally. There are three types of chocolate: dark, milk and white chocolates. Most of the benefits of chocolate consumption are associated with the dark brand. In the last decade, studies have shown that chocolate consumption can play an important role in the reduction of risks or delaying the development of cardiovascular diseases, cancer and other age-related diseases. It has also been linked positively to anticarcinogenic activity in human cells, hypertension, diabetes and sexual weakness. It's newly found reputation as an aphrodisiac, stems from the ability of its sweet and fatty nature to simulate the hypothalamus, which induces pleasure sensation and affects the level of serotonin in the brain (Afoakwa, 2008).

Cocoa products contain flavonoids and amino acids, and these have been cited as the source of its beneficial effects, while carbohydrates, theobromine and lead have been mentioned as responsible for the negative effects. The flavonoids belong to a large and complex group of compounds called polyphenols and are found in plant products, mainly fruits and vegetables. The phenols in cocoa products have been associated with antioxidant properties, reduction in migraine, protection of arteries from plaque formation and prevention of LDL formation two hours after consuming dark chocolate and perceptible lowering of blood pressure. Some studies have also linked chocolate consumption to muscle recovery and delayed brain function decline (Reuters, 2007). Protein is broken down in the body to form twenty amino acids needed by the body. Eight of these are called essential, which means they are not made by the human body itself and must be supplied from outside. Fourteen of the twenty amino acids found in the body, including the eight essential ones, have been 
found in cocoa. In addition to building cells and repairing tissues, amino acids also have antioxidant properties, and they form antibodies to combat invading bacteria and viruses (Awuah, 2002).

While international standards are such that the pesticides used in the field can hardly find their way into chocolate, a number of documented negative effects have been associated with some of the natural and absorbed constituents of cocoa. Perhaps the major one is obesity. It is believed that the amounts of dark chocolate that needs to be consumed in order to experience the good benefits of the product could lead to obesity and its resultant negative effects. Although it is not supported by scientific studies, it is also believed that chocolate consumption can lead to acne (www.chocolate.gourmetrecipe.com). The heavy metal, lead, is known to maintain a high solubility in chocolate, and this may lead to lead poisoning (Rankin et al, 2005). Chocolate is also known to be toxic to some animals like horses, dogs, parrots, cats and small rodents, because they are unable to metabolize the theobromine which is found in chocolate (Drolet et al, 1984; Blakemore and Shearer, 1943).

\section{Pests and diseases of cocoa}

The increasing world population cannot be sustained without the use of pesticides in food production. Their usage therefore benefits not only farmers but also consumers. Pesticides are used to reduce food losses not only during production, but also during the post-harvest storage stage (Moy and Wessel, 2000). The general pest control strategy is for the intervention to destroy the pests feasting on the crops, but at the same time not to damage the produce so much as to render them unhealthy or unprofitable. This means looking for the thin line which separates good practices from bad. Good agricultural practice (GAP) requires good timing and proper application. The crops are sprayed on the advice of specialists at an opportune time in the reproductive cycle of the pest, when the highest numbers could be eliminated. Also in order to maintain the activities of friendly insects the area of application of the insecticides should be clearly delineated.

The cocoa tree and its pod can be attacked by different species of insects, fungal diseases and rodents (Entwistle, 1972). The major diseases affecting cocoa in Ghana are given in Table 1. The most important of these are Phytophthora pod rot, commonly called "black pod", and locally known as 'akate'; and the swollen shoot virus, also known locally as 'cocoa sasabro'. The black pod rot, a fungal disease which appears as characteristic brown necrotic lesions on the pod's surface and as rotting of the beans, does the most damage to cocoa. An estimated $30 \%$ of annual cocoa production is lost to it, especially during years of high rainfall. At 2005 cocoa bean prices this is an estimated US $\$ 1.5$ billion in lost revenue (www.icco.org). Other estimates put the loss specifically at 450 thousand metric tonnes annually, while 250, 200 and 50 thousand MT are lost to witches' broom, capsids, and the swollen shoot virus (CSSV), respectively (www.dropdata.org). Witches' broom and frosty pod rot are predominant in Latin America, while the black pod and CSSV are common in West Africa. These diseases are counted by breeding disease-resistance species, sanitation and the use of fungicides (Bastos, 1996; Opoku et al, 2007).

Most insects which attack cocoa are of the bug or miridiae family. This is a large family of insects of which capsids, the most well-known, have achieved their notoriety from the degree of havoc they can wreck on cash crops like cocoa. They feed on plants by piercing the tissue and sucking their juices. Capsids are small, terrestrial insects, usually oval-shaped or elongate and measuring less than $12 \mathrm{~mm}$. They were identified as pests at the turn of the last century and are the main insects that feed on cocoa in Africa (Mahot et al., 2005). 


\begin{tabular}{|c|c|c|}
\hline Disease & $\begin{array}{l}\text { Type of Infection } \\
\text { (Causal agent) }\end{array}$ & Symptoms \\
\hline Black pod & $\begin{array}{l}\text { Fungus } \\
\text { (Phytophthora spp.) }\end{array}$ & $\begin{array}{l}\text { Pod rots, go brownish-black. Beans destroyed } \\
\text { in immature pods. Could result in die-back }\end{array}$ \\
\hline Brown root rot & $\begin{array}{l}\text { Fungus } \\
\text { (Fomes noxius) }\end{array}$ & $\begin{array}{l}\text { Leaves fall prematurely and die-back of twigs } \\
\text { occurs. Fungus fruit bodies on root and dead } \\
\text { trunks. Soil is affected }\end{array}$ \\
\hline Cocoa necrosis & $\begin{array}{l}\text { Virus } \\
\text { (Cocoa necrosis virus) }\end{array}$ & $\begin{array}{l}\text { Leaves show bands of transparent lesions } \\
\text { often with perforated centers }\end{array}$ \\
\hline Collar crack & $\begin{array}{l}\text { Fungus } \\
\text { (Armillaria mellea) }\end{array}$ & $\begin{array}{l}\text { Longitudinal cracking of trunk from ground } \\
\text { level to about } 1.2 \mathrm{~m} \text { upwards, fills with } \\
\text { cream-coloured mycelium }\end{array}$ \\
\hline Collar rot & $\begin{array}{l}\text { Fungus } \\
\text { (Ustulina zonata) }\end{array}$ & $\begin{array}{l}\text { Defoliation and death of plants. White fan- } \\
\text { shaped patches of mycelium are produced } \\
\text { underneath bark and roots }\end{array}$ \\
\hline Cushion gall & $\begin{array}{l}\text { Fungus } \\
\text { (Calonectria rigidiuscula) }\end{array}$ & Excessive production of buds at the nodes \\
\hline $\begin{array}{l}\text { Vascular } \\
\text { Streak } \\
\text { Die-back }\end{array}$ & $\begin{array}{l}\text { Fungus } \\
\text { (Oncobasidium theobroma) }\end{array}$ & $\begin{array}{l}\text { Leaves turn yellow and fall prematurely. } \\
\text { Smaller branches wither starting from the } \\
\text { tips }\end{array}$ \\
\hline $\begin{array}{l}\text { Horse hair } \\
\text { blight }\end{array}$ & $\begin{array}{l}\text { Fungus } \\
\text { (Marasmius equicrinis) }\end{array}$ & $\begin{array}{l}\text { Network of black threads which spread } \\
\text { throughout the canopy, smothers shoots } \\
\text { growth }\end{array}$ \\
\hline Mealy pod & $\begin{array}{l}\text { Fungus } \\
\text { (Trachysphaera fructigena) }\end{array}$ & $\begin{array}{l}\text { Pods turn brown, becomes encrusted with } \\
\text { white to pinkish mealy growth of the fungus }\end{array}$ \\
\hline Mistletoe & $\begin{array}{l}\text { Flowering Plant } \\
\text { (Tapinanthus bangwensis) }\end{array}$ & $\begin{array}{l}\text { Parasitic flowering plant on host branches. } \\
\text { Part of branch withers }\end{array}$ \\
\hline Pod rot & $\begin{array}{l}\text { Fungus } \\
\text { (Botryodiphlodia } \\
\text { theobromae) }\end{array}$ & $\begin{array}{l}\text { Appears as brown necrotic areas with } \\
\text { concentric rings of black spots. Pods are later } \\
\text { covered with black sooty powder }\end{array}$ \\
\hline Red rust & $\begin{array}{l}\text { Alga } \\
\text { (Cephaleuros mycoidea) }\end{array}$ & $\begin{array}{l}\text { Reddish patches on leaves and twigs; leaves } \\
\text { are shed prematurely }\end{array}$ \\
\hline Swollen shoot & $\begin{array}{l}\text { Virus } \\
\text { (Cocoa swollen shoot } \\
\text { virus) }\end{array}$ & $\begin{array}{l}\text { Swelling of chupons and twigs; leaves } \\
\text { develop yellow patterns, get crinkled and } \\
\text { malformed }\end{array}$ \\
\hline White Root & $\begin{array}{l}\text { Fungus } \\
\text { (Fomes lignosus) }\end{array}$ & $\begin{array}{l}\text { Premature defoliation, death of twigs, pods } \\
\text { are small }\end{array}$ \\
\hline $\begin{array}{l}\text { White thread } \\
\text { Blight }\end{array}$ & $\begin{array}{l}\text { Fungus } \\
\text { (Marasmius scandens) }\end{array}$ & $\begin{array}{l}\text { Leaves are covered and killed in a network of } \\
\text { white mycelial threads }\end{array}$ \\
\hline
\end{tabular}

Source: Offei et al. (2005)

Table 1. Diseases of Cocoa in Ghana

\subsection{National cocoa pests and diseases control programme}

Throughout the 90 's, the tonnage of cocoa produced annually rarely exceeded 400,000 metric tonnes. This situation was attributed to a variety of causes, although the prevalence of pests and cocoa diseases was seen as the main reason. Crop losses due to mirids alone 
were estimated at between $25-35 \%$ per annum. To reverse this trend, the government of Ghana in the year 2000 introduced the national Cocoa Diseases and Pests Control Programme, CODAPEC, popularly known as "mass spraying", to combat the resurgence of mirids and black pod diseases on cocoa farms. This opportunity was also to be used to train farmers and technical personnel in the scientific methods of pests and diseases control (Adjinah and Opoku, 2010). Participants were trained in the dosage of the various pesticides, dangers of exposure to pesticides, importance of the use of protective clothing, observance of personal hygiene, environmental safety issues, first-aid, techniques of application and handling and disposal of empty containers. Lessons were given through radio programmes, town meetings and 'training-of-trainers' workshops. Table 2 gives the brands of pesticides, approved by the Cocoa Research Institute of Ghana (CRIG), which are currently in use on Ghanaian cocoa farms under the CODAPEC programme and their application frequency.

\begin{tabular}{|c|c|c|c|}
\hline Pesticide used & Active ingredient & $\begin{array}{l}\text { Method of } \\
\text { application }\end{array}$ & Frequency \\
\hline \multicolumn{4}{|l|}{ Fungicides } \\
\hline Ridomil 72 plus & $12 \%$ metalaxyl, $60 \%$ & & \\
\hline WP & Cuprous oxide & & \\
\hline Nordox $75 \mathrm{WP}$ & $\begin{array}{l}86 \% \text { Cuprous oxide, } 14 \% \\
\text { inert }\end{array}$ & & \\
\hline $\begin{array}{l}\text { Funguran } \mathrm{OH} \\
\mathrm{WP}\end{array}$ & Cuprous hydroxide & Knapsack & 3 times during \\
\hline Champion WP & $77 \%$ cupric hydroxide & sprayer & each cocoa season \\
\hline Kocide $101 \mathrm{WP}$ & Cupric hydroxide & & \\
\hline Fungikill WP & Cupric hydroxide + & & \\
\hline Metalm 72 Plus & metalaxyl & & \\
\hline WP & Cuprous oxide + metalaxyl & & \\
\hline \multicolumn{4}{|l|}{ Insecticides } \\
\hline Akatemaster & Bifenthrin & & \\
\hline Actara & Thiamethoxam & & \\
\hline Cocostar 210 EC & $\begin{array}{l}\text { Bifenthrin + Pirimiphos- } \\
\text { methyl }\end{array}$ & $\begin{array}{l}\text { Knapsack } \\
\text { sprayer }\end{array}$ & $\begin{array}{l}\text { Twice during each } \\
\text { cocoa season }\end{array}$ \\
\hline Confidor 200SL & Imidacloprid & & \\
\hline Carbamult & Promecarb & & \\
\hline
\end{tabular}

Table 2. Pesticides approved for used in the control of mirids and black pod disease under the CODAPEC programme

The black pod control programme covered all cocoa-growing districts in the Volta, Brong Ahafo and parts of Western, Ashanti and Eastern Regions. Spraying against mirids, on the other hand, covered the Central, Eastern and parts of Western and Ashanti Regions. Spraying gangs were established at each spraying centre. A gang of ten (for black pod control) and six (for mirids control) had a supervisor each responsible for the general execution of the programme at the unit level. One mechanic was attached to a group of 20 gangs to oversee the maintenance and repairs of the spraying machines. The farmers, who 
were direct beneficiaries of the exercise, were themselves responsible for the sanitation practices, i.e. brushing, pruning, shade management and removal of diseased pods from the farms. They also provided water for spraying and were expected to monitor the activities of the sprayers on the farm. The spraying is carefully done using a portable petrol-enginedriven knapsack mist-blowers, which combines the idea of low-volume application of sprays with the principle of using fan-driven air to carry the spray up into the trees.

As a result of this initiative, between the period 2002-2004, nearly 600,000 ha involving about 360,942 farms and 330,121 individual farmers, were sprayed three times each season against the black pod diseases, while an estimated 826,141 ha involving 470,801 and 446,593 farmers were sprayed twice each season in the mirids control exercise. From the 2001/2002 season when beans output of 380,000 metric tons was recorded, production jumped to about 500,000 metric tonnes in the 2002/2003 season and almost doubled in the 2003/2004 season to an all-time high of over 736,000 metric tonnes.

Started ten years ago, the mass spraying exercise has now become a permanent fixture in all the 72 geographical districts in the cocoa-growing areas with the following breakdown: 21districts for black pod spraying only, 35 districts for mirids only, and 16 for both programmes. District Task Forces (DTF) and Local Task Forces (LTF), have been formed in each operational district and local area, respectively. The DTF manages the project at the district level and is in charge of gang recruitment, storage, distribution of inputs and logistics and general supervision. The LTF on the other hand, handles project management at the village level and is responsible for the planning and execution of the programmes at that level. Table 3 gives the seasonal cocoa production figures along with the amounts of fertilizers and pesticides which have been used in Ghana in recent years. The table indicates clearly that cocoa production has increased significantly in the last decade, but it has been at the expense of more pesticides and fertilizers. Data obtained from COCOBOD indicate that fourteen different kinds of insecticides and fungicides have been used for spraying farms since the start of the mass spraying exercise. Even with the limited data provided, the increase in pesticide usage per unit weight of cocoa over the period is evident. The same trend applies to fertilizer usage. Serious attention must be paid to these trends beyond the normal concerns with maximum residue limits (MRLs) which international traders focus on. The impact of these prodigious amounts of chemicals used in cocoa production on the environment as a whole can be determined through life-cycle analyses (Ntiamoah and Afrane, 2009).

\begin{tabular}{|c|c|c|c|c|c|c|}
\hline \multirow{2}{*}{$\begin{array}{l}\text { Crop } \\
\text { Season }\end{array}$} & \multirow{2}{*}{$\begin{array}{c}\text { Cocoa } \\
\text { Production } \\
\left(10^{6} \mathrm{~kg}\right)\end{array}$} & \multirow{2}{*}{$\begin{array}{l}\text { Total }^{a} \\
\text { Fertilizer } \\
\text { Used } \\
\left(10^{6} \mathrm{~kg}\right)\end{array}$} & \multicolumn{2}{|c|}{ Pesticides Usage $^{a}$} & \multirow{2}{*}{$\begin{array}{c}\text { Fertilizer } \\
\text { used per } \\
\text { MT }\end{array}$} & \multirow{2}{*}{$\begin{array}{c}\text { Fungicides } \\
\text { used per } \\
\text { MT }\end{array}$} \\
\hline & & & $\begin{array}{l}\text { Insecticides } \\
\text { (liters) }\end{array}$ & $\begin{array}{l}\text { Fungicides } \\
\text { (MT) }\end{array}$ & & \\
\hline $2004 / 05$ & 601.9 & - & 1023.6 & 1120.0 & - & 1.86 \\
\hline $2005 / 06$ & 740.4 & - & 745.0 & 759.4 & - & 1.03 \\
\hline $2006 / 07$ & 614.5 & 70.1 & 590.0 & 1120.0 & 0.11 & 1.83 \\
\hline $2007 / 08$ & $729.0^{\dagger}$ & 55.8 & 1020.0 & 1290.0 & 0.08 & 1.77 \\
\hline $2008 / 09$ & $662.0^{\dagger}$ & 105.0 & 1760.0 & 1800.0 & 0.16 & 2.72 \\
\hline $2009 / 10$ & $632.0^{\dagger}$ & 130.0 & 2300.0 & 1997.7 & 0.20 & 3.16 \\
\hline
\end{tabular}

tSource: ICCO Quarterly Bulletin of Cocoa Statistics, Vol. XXXVI, No. 4, Cocoa year 2009/2010. Published: 3011-2010; all others in this column from, The State of the Ghanaian Economy, 2007. a Source: COCOBOD, Ghana.

Table 3. Seasonal Cocoa Production, Fertilizer and Insecticide Usage in Ghana, 2004-2010 
While non-chemical means of managing cocoa pests and diseases are widely recommended, the need for agro-chemicals to manage cocoa pests and diseases is unavoidable and will continue for years to come. However, the effects of continued exposure of users of pesticides, environmental risks, issues of pest resistance and possible hazards for consumers require a re-examination of the benefits of pesticide application and the risks involved. Hence the introduction of Good Agricultural Practices (GAP) to considerably mitigate, if not eliminate, the problems associated with the excessive and unnecessary application of pesticides. High residue levels and tainting of the beans could lead to their rejection on the international market. Testing for residues is carried out following internationally agreed and validated methods (Moy and Wessel, 2000). Though some insecticide residues are sometimes found in the shells, they are hardly found in the nib which is used in chocolate manufacture.

\section{Socio-economic impacts of pesticides use on the cocoa industry}

In terms of output the CODAPEC programme was a tremendous success, because it was able to resuscitate cocoa production in Ghana. The country continues to benefit not only because of increased output, but also because of the high prices the crop is currently enjoying on the international market. Thus the benefits to the economy as a whole were obvious. What was not so obvious was the direct benefit to the cocoa farmers.

In order to assess the impact of the programme on these farmers, Abankwa et. al (2010), conducted a study in a typical cocoa-growing district, Ahafo Ano South, located at the north-western section of the Ashanti Region of Ghana. The study found that while the farmers could not take their children to better basic schools, they were able to afford school uniforms and other basic educational needs for them. They also found that farmers were able and more willing to visit hospitals instead of self-medicating or using herbal treatment. The improvements brought about by the programme seemed to benefit more farmers with higher levels of education, the study showed.

One poignant conclusion of the study was that, while the price of cocoa was reviewed upwards every year over the first five years of the programme, these increments did not translate into increased purchasing power of farmers. They were not able to afford assets like radios, televisions, mattresses and vehicles any better, five years after the programme was started. Table 4 gives the nominal and actual farmers' income over the period 20012005. While the nominal figures trend upwards annually as a result of the increases in cocoa price, the actual income (calculated using CPI of 1997 as base) goes down every year due to the effect of inflation.

\begin{tabular}{|l|c|c|c|}
\hline Year & Consumer Price Index & Nominal Income & Actual Income \\
\hline 2001 & 216.4 & 631.5 & 294.6 \\
\hline 2002 & 246.2 & 679.9 & 276.2 \\
\hline 2003 & 311.8 & 753.3 & 241.6 \\
\hline 2004 & 351.2 & 805.5 & 229.4 \\
\hline 2005 & 404.3 & 939.3 & 232.3 \\
\hline
\end{tabular}

Table 4. Variations in Farmers' Income, 2001-2005 (Source: Abankwa et al. 2010) 
From the point of view of COCOBOD, the implementers of the programe, the mass spraying exercise has been a roaring success, because of the increased yield it has generated, the renewed enthusiasm for cocoa cultivation that it has awoken in farmers, and also because of the 60,000 direct jobs it has created for sprayers, supervisors and mechanics in the rural areas of the country (Adjinah and Opoku, 2010). According to the Seed Production Unit of COCOBOD, demand for planting materials has gone up significantly because new farms are been established and old ones rejuvenated (Adjinah and Opoku, 2010). Farmers now clearly see cocoa farming as a profitable venture, especially with the continued reduction in inflation and the general improvement in the economy.

\section{Potential ecological impacts of pesticides use in cocoa production}

A proper assessment of the effect of pesticides and other chemicals used during cocoa production and processing on the environment and human health, has to begin with an effective quantification of the chemicals released into the environment and their impact on various aspects of human life and the environment. For this purpose, one of the widely accepted modern methods for examining the environmental impacts associated with a service or a product is the life cycle assessment (LCA) technique.

\subsection{Life cycle assessment methodology}

The Society of Environmental Toxicology and Chemistry (SETAC), defines LCA as:

"an objective process to evaluate the environmental burdens associated with a product, process or activity by identifying and quantifying energy and materials used and wastes released to the environment; to assess the impact of those energy and material uses and releases to the environment; and to identify and evaluate opportunities to effect environmental improvements. The assessment includes the entire life cycle of a product, process or activity, encompassing extracting and processing raw materials; manufacturing, transportation and distribution; use, re-use, maintenance; recycling, and disposal" (Consoli et al, 1993).

The International Organization for Standardization (ISO) has also provided very relevant input to the definition of LCA. According to ISO 14040 (1997), LCA is

"a compilation and evaluation of the inputs, outputs and the potential environmental impacts of a product system throughout its life cycle. A product system is a collection of materially or energetically connected unit processes, which performs one or more defined functions".

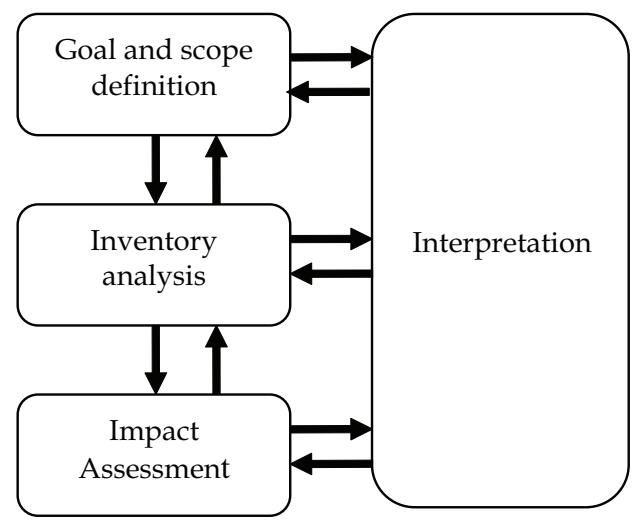

Fig. 2. Components of a Life Cycle Assessment (ISO 14040) 
The standard LCA methodology consists of four stages, namely, goal and scope definition, inventory analysis, impact assessment and interpretation of results. These are represented pictorially in Figure 2. The goal and scope definition means a clear statement of the reasons for performing the study, the intended use of the results and the specification of the basic parameters of LCA study, such as the functional unit, system boundaries, allocation rules, data quality and simplifications. According to ISO 14040:1997, the functional unit is defined as 'the quantified performance of a product system for use as a reference unit in an LCA study'. For a product this usually simply involves specifying the weight, volume or number of a unit amount. Thus it has to be clearly defined and measurable. The primary purpose of the functional unit is to provide a reference to which the input and output data can be normalized in a mathematical sense.

The LCI stage involves collecting data concerning resource usage, energy and materials consumption, emissions and products resulting from each activity in the production system. As mentioned above, all these in- and out flows are calculated on the basis of the functional unit. In the third phase, the LCIA phase, the data collected is classified into specific categories and aggregated. This stage is composed of several mandatory elements and there are also optional elements for normalization, grouping or weighting of the indicator results and data quality analysis techniques. Finally, the life cycle interpretation is a procedure to identify, qualify, check and evaluate the information from the results of the LCI and/or LCIA of a product system. It is important to appreciate the reversible nature of an LCA study. It may be necessary, at some point, to go back to the previous stage to question and probe the results obtained. This is commonly done in LCA analysis, and arrows have been turned round to emphasize this point.

In this study, LCA was conducted following the guidelines stated above to determine the potential environmental impacts of producing $1 \mathrm{~kg}$ of chocolate in Ghana. The boundaries of the system studied have been shown in Figure 1, the process flow chart for chocolate production. (Those processes with broken boundaries were excluded from the analysis.) The inputs and outputs data collected in this work from the field and standard LCA databases are summarized in Table 5. Using the ISO series and CML 2001 database from the Centre for Environmental Science at the University of Leiden for impact assessment, the results given in Table 6 were obtained for the quantified impact scores for the selected relevant environmental impact categories (Ntiamoah and Afrane, 2009). Data storage and analysis were performed using the GaBi 4 LCA software.

The overall scores show that freshwater aquatic ecotoxicity and human toxicity are the most significant environmental impacts made by the process. In order to examine closely the contribution of the various stages of production to the overall impacts, Figure 3 was plotted. The percentage contribution of each stage to the total impact score of each category is given in this figure. The cocoa production stage was identified as the key life-cycle stage in terms of environmental impacts, as it makes the largest contribution to five out of the eight environmental impact categories considered in the study. The figure shows that it this is the most predominant contributor to eutrophication, ozone depletion, freshwater aquatic ecotoxicity, human toxicity, and terrestric eco-toxicity, with average contributions greater than $95 \%$. Indeed the production and use of fertilizers and pesticides account for almost all the environmental burdens in the cocoa production stage. The significance of each of these environmental categories which are prominent, in cocoa production will be examined in turn. 


\begin{tabular}{|c|c|c|}
\hline INPUTS/OUTPUTS & Amount & Unit \\
\hline \multicolumn{3}{|l|}{ Energy Inputs } \\
\hline Electricity, (from national grid) & 3.1716E-01 & MJ \\
\hline Diesel & 5.3142E-02 & $\mathrm{Kg}$ \\
\hline Petrol & 8.9967E-03 & $\mathrm{Kg}$ \\
\hline \multicolumn{3}{|l|}{ Materials Inputs } \\
\hline Water & $5.1274 \mathrm{E}+00$ & $\mathrm{Kg}$ \\
\hline Fertilizer (N:P:K $\quad 0: 22: 18+9 \mathrm{CaO}+7 \mathrm{~S}+6 \mathrm{MgO})$ & $1.4590 \mathrm{E}-01$ & $\mathrm{Kg}$ \\
\hline \multicolumn{3}{|l|}{ Pesticides } \\
\hline -Fungicides & $7.4200 \mathrm{E}-03$ & $\mathrm{Kg}$ \\
\hline -Insecticides & 8.0000E-04 & $\mathrm{Kg}$ \\
\hline Land use & 3.9218E-05 & $\mathrm{Ha}$ \\
\hline \multicolumn{3}{|l|}{ Products/By-Products } \\
\hline Chocolate & $1.0000 \mathrm{E}+00$ & $\mathrm{Kg}$ \\
\hline Cocoa Liquor & $3.1948 \mathrm{E}-01$ & $\mathrm{Kg}$ \\
\hline Cocoa Butter & $2.3125 \mathrm{E}-01$ & $\mathrm{Kg}$ \\
\hline Cocoa Cake & $2.6875 \mathrm{E}-01$ & $\mathrm{Kg}$ \\
\hline Cocoa Powder & $7.5000 \mathrm{E}-02$ & $\mathrm{Kg}$ \\
\hline Cocoa Shells & $9.8000 \mathrm{E}-02$ & $\mathrm{Kg}$ \\
\hline \multicolumn{3}{|l|}{ Air Emissions } \\
\hline Dust (PM2,5 - PM10) [Particles to air] & $2.5000 \mathrm{E}-03$ & $\mathrm{Kg}$ \\
\hline Sulphur dioxide [Inorganic emissions to air] & 8.0000E-03 & $\mathrm{Kg}$ \\
\hline Heavy metals to air & 3.5745E-05 & $\mathrm{Kg}$ \\
\hline Carbon dioxide [Inorganic emissions to air] & $2.3790 \mathrm{E}-01$ & $\mathrm{Kg}$ \\
\hline Carbon monoxide [Inorganic emissions to air] & $8.4100 \mathrm{E}-03$ & $\mathrm{Kg}$ \\
\hline Pesticides to air & $8.1308 \mathrm{E}-04$ & $\mathrm{Kg}$ \\
\hline \multicolumn{3}{|l|}{ Water Emissions } \\
\hline Biological oxygen demand (BOD) & 5.0437E-12 & $\mathrm{Kg}$ \\
\hline Chemical oxygen demand (COD) & 9.8212E-12 & $\mathrm{Kg}$ \\
\hline Nitrates & $3.7500 \mathrm{E}-15$ & $\mathrm{Kg}$ \\
\hline Oil \& Grease & 1.0000E-14 & $\mathrm{Kg}$ \\
\hline Phosphates & 4.4204E-14 & $\mathrm{Kg}$ \\
\hline Total dissolved solids & $5.1525 \mathrm{E}-12$ & $\mathrm{Kg}$ \\
\hline Total suspended solids & 4.1287E-12 & $\mathrm{Kg}$ \\
\hline Heavy metals to fresh water & $7.4761 \mathrm{E}-04$ & $\mathrm{Kg}$ \\
\hline Pesticides to fresh water] & $3.6880 \mathrm{E}-03$ & $\mathrm{Kg}$ \\
\hline \multicolumn{3}{|l|}{ Soil Emissions } \\
\hline Pesticides to soil & 9.4477E-04 & $\mathrm{Kg}$ \\
\hline Heavy metals to agricultural soil & $4.1870 \mathrm{E}-05$ & $\mathrm{Kg}$ \\
\hline
\end{tabular}

(Source: Ntiamoah and Afrane, 2009.)

Table 5. Summary of input/output data for the production of $1 \mathrm{~kg}$ chocolate from Ghanaian cocoa beans, 2004/2005 season. 


\begin{tabular}{lll}
\hline Environmental Impact Category & $\begin{array}{l}\text { Overall } \\
\text { Impact Score }\end{array}$ & Unit \\
\hline Acidification Potential (AP) & $9.7351 \mathrm{E}-03$ & $\mathrm{~kg} \mathrm{SO}_{2}$ \\
Eutrophication Potential (EP) & $9.1568 \mathrm{E}-04$ & $\mathrm{~kg} \mathrm{PO}_{4}^{3-}$ \\
Freshwater Aquatic Ecotoxicity Potential (FAETP) & $5.0797 \mathrm{E}+00$ & $\mathrm{~kg}{ }^{*} \mathrm{DCB}$ \\
Global Warming Potential (GWP) & $3.5602 \mathrm{E}-01$ & $\mathrm{~kg} \mathrm{CO} 2$ \\
Human Toxicity Potential (HTP) & $4.4426 \mathrm{E}+00$ & $\mathrm{~kg}{ }^{*} \mathrm{DCB}$ \\
Ozone Layer Depletion Potential (ODP) & $4.9805 \mathrm{E}-09$ & $\mathrm{~kg}$ * 11 \\
Photochem. Ozone Creation Potential (POCP) & $9.3002 \mathrm{E}-04$ & $\mathrm{~kg}$ Ethene \\
Terrestrial Ecotoxicity Potential (TETP) & $6.3796 \mathrm{E}-03$ & $\mathrm{~kg}$ *DCB \\
\hline
\end{tabular}

${ }^{*} \mathrm{DCB}$ is 1,4 dichlorobenzene, ${ }^{*} \mathrm{R} 11$ is trichlorofluoromethane.

Table 6. Characterization results (overall impact scores) for the production of $1 \mathrm{~kg}$ chocolate in Ghana, obtained by using the CML 2001 method

\section{Eutrophication}

Eutrophication or nutrification is a measure of the over-fertilisation of soils and contamination of water-bodies with nutrients. In waters it causes excessive algal growth and negative modification of the aquatic ecosystems resulting in oxygen depletion and death of certain species. In soils, on the other hand, it promotes monocultures and loss of biodiversity (Heijungs et al (1992) and Guinee et al (2001)). Since nitrogen and phosphorus are the limiting nutrients for most of the aquatic systems, leaching of these nutrients into waterbodies results in eutrophication. High nitrate levels have been found in drinking water in developing countries. This has been linked to a disease known as methaemoglobinaemia, commonly referred to as the blue-baby syndrome, in agricultural areas (Pretty and Conway, 1988; Conway and Pretty, 1988). Although incidence of this disease in Ghana has not been reported in the literature, to the best of our knowledge, given the large amounts of fertilizer being used in cocoa production, possible contamination of water bodies need to be a matter of concern to stakeholders in the industry.

\section{Freshwater Aquatic, Terrestial and Human Toxicity}

From the results of Figure 2, not only are freshwater aquatic and human toxicity limited almost exclusively to the cocoa production stage, but they have the highest numerical values in the figure, which makes them more significant than the others. Terrestial toxicity, though not of the same magnitude as the other two, is nevertheless important. Toxicity to humans, flora and fauna is caused by a variety of substances, ranging from carcinogens to persistent toxins such as heavy metals which find their way into the food chain. The probability exists for harmful chemicals directly or indirectly poisoning some organisms and ultimately eliminating them from the ecosystem, and thereby restricting the biodiversity of the region and upsetting the food chain.

\section{Acidification}

Acidification is an indication of the gradual degradation of the soil and it is caused by acid solution formed when pollutants generated from the combustion of fuels are released into the atmosphere. In technical terms, it is caused by the build-up of protons in soils and lakes. Hauschild and Wenzel, (1998) describe it as a fall in the capacity of the soil to neutralize the acids that run through it. Higher acidity in certain types of soils can lead to the mobilisation of different fixed ions, which are then absorbed by plants to their detriment. Water which 
seep through acidic soils can harm aquatic ecosystems in the different lakes and rivers and in some severe cases, acidic water has been known to leave some water-bodies lifeless (Mannion and Bowlby, 1992). Acidification can be caused directly by acids and indirectly by acidic anhydrides (sulphur dioxide and trioxide and oxides of nitrogen) and ammonia.
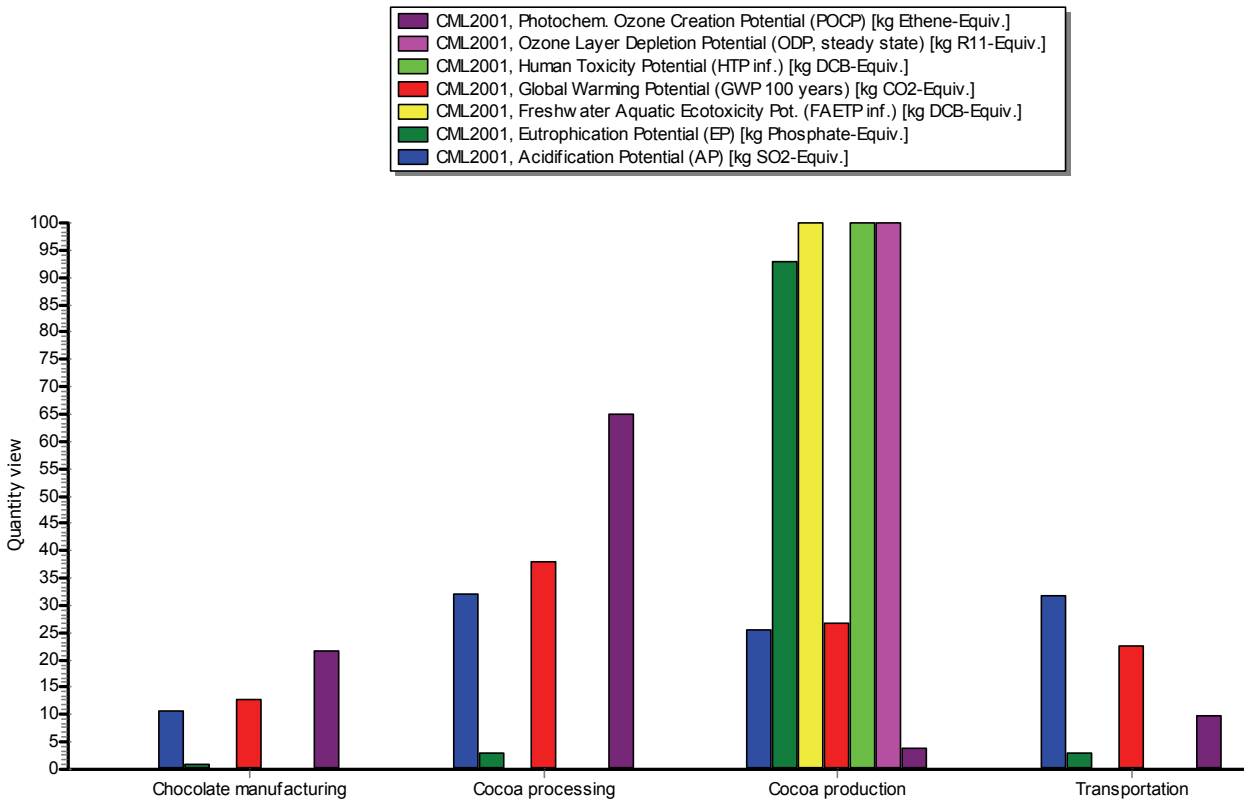

Fig. 3. Relative contribution of different stages of the life-cycle to the various environmental categories

\section{Ozone layer Depletion Potential}

The thinning of the ozone layer in the stratosphere is allowing increased levels of ultraviolet radiation to reach the earth, leading to diseases in humans (skin cancer and cataracts) and adverse effect on ecosystems. Ozone layer depletion is caused by the emission of halons and CFCs during the production of pesticides. These processes are based on complicated reaction systems, including both solid phase and gaseous phase reactions, and a limited number of substances are involved (Hauschild and Wenzel, 1998). Most notably methane, nitrous oxide, water vapour, chlorine and some bromine compounds, are responsible for the breakdown of ozone molecules. Human activities have increased the amount of substances involved in the breakdown of ozone and especially stable, long-lived chlorine and bromine containing hydrocarbons (i.e. chlorofluorocarbons or CFCs, tetrachloromethane, trichloroethane, etc.) are believed to contribute significantly. Fortunately the contribution to ozone-layer thinning, as a result of cocoa production and processing, turns out to be the least significant, according to Figure 3.

\section{Conclusion}

The use of pesticides is often advisable and sometimes essential when a crop is threatened. Integrated pest management is a concept which is now generally known and widely 
accepted, and it is hoped that the judicious use of pesticides will be accepted as an integral part of pest management strategy. Technologies are presently available for the safe use of pesticides in cocoa and awareness of their correct and proper use needs to be stimulated (Bateman, 2008). However, introducing Good Agricultural Practices to the more than three million (often illiterate) smallholder farmers in the world cocoa economy is a major challenge. Ghana is making some strides in this area.

The clear indications are that the current agricultural practices for cocoa production are not sustainable, from both the environmental and economic perspective. Continued increase in the costs and amounts of chemicals put into the environment does not portend well for the future of this cash crop. The study has shown that current pests and diseases control practices in Ghanaian cocoa production which rely primarily on chemical methods, though well administered, results in more environmental damage. In the long term integrated pest management (IPM), which encourages natural control of pest populations, promises to reduce the use of pesticides. Some of the techniques used in this approach include enhancing natural enemies, planting pest-resistant crops, and, when absolutely necessary, efficient and judicious use of pesticides.

Pesticides continue to be attractive to most farmers and governments because they are simple to use, compared to the IPM methods, and returns on investments are not only good, but are predictable. A switch to IPM must be preceded by careful planning, and intensive education and training at the farm level, along with continuing research. In addition, promoting IPM will definitely require adjusting those subsidies and policies that encourage extensive pesticide use; otherwise farmers may not be able to resist the temptation of going back to their old ways.

\section{Acknowlegements}

The readiness of the staff of CODAPEC, Research and HI-TECH Divisions of COCOBOD, Accra, and the Cocoa Research Institute of Ghana at Tafo, to assist during the data collection stage was commendable and is hereby acknowledged.

\section{References}

Abankwah, V.; Aidoo, R.; Osei, R.K (2010).: Socio-Economic Impact of Government Spraying Programme on Cocoa Farmers in Ghana, Journal of Sustainable Development in Africa (Volume 12, No.4, 2010)

Acquaah, B. (1999): Cocoa Development in West Africa (The Early Period with particular reference to Ghana), Ghana Universities Press, Accra, Ghana

Adjinah, K.O. and Opoku, I.Y. (2010): The National Cocoa Diseases and Pest Control (CODAPEC): Achievements and Challenges myjoyonline - Myjoyonline.com Feature Article, Wed, 28 Apr 2010

Afoakwa, E.O. (2008): Cocoa and chocolate consumption- Are there aphrodisiac and other benefits for human health? S. Afr J Clin Nutr, 21 (3) 107-113

Appiah, M. R. (2004): Impact of Cocoa Research Innovations on Poverty Alleviation in Ghana. Ghana Academy of Arts and Sciences Publication. pp1, 17-19.

Akrofi, A.Y., Baah, F.(Eds) Proceedings of the $5^{\text {th }}$ INCOPED International Seminar on Cocoa Pests and Diseases, International

Permanent Working Group for Cocoa Pests and Diseases (INCOPED) Secretariat, Cocoa Research Institute, Tafo, Ghana 
Aryeetey, E. (2007) (Ed). State of the Ghanaian Economy, 2007; Report of the Institute of Social, Statistical and Economic Research, ISSER, UG, Legon, Ghana

Awua, P. K. (2002): The Success Story of Cocoa Processing and Chocolate Manufacturing in Ghana. David Jamieson \& Associates Ltd., Essex U.K. pp 1-4, 33-56.

Bastos, C.N.,Biological Control of Crinipellis perniciosa by an isolate of Trichoderma sp. Proceedings of the $5^{\text {th }}$ INCOPED International Seminar on Cocoa Pests and Diseases, INCOPED Secretariat, Cocoa Research Institute, Tafo, Ghana

Bateman, R. (2008): Pesticides Use in Cocoa, A Guide for Training, Administrative and Research Staff, ICCO/IPARC Consultant Report, v.12/08/2008

Blakemore F., Shearer G.D. (1943): The poisoning of livestock by cacao products. Vet Record 1943;55 (15).

Consoli, F., Allen D., Boustead, I., Fava J., Franklin, W., Jensen, A. A., de Oude, N., Parrish, R., Perriman, R., Postlethwaite, D., Quay, B., Sequin, J. and Vigon, B. (1993): Guidelines for Life-Cycle Assessment: A Code of Practice; Society for Environmental Toxicology and Chemistry, Brussel, Belgium.

Conway, G. R. and Pretty, J. N. 1988, 'Fertilizer risks in developing countries', Nature, Vol. 334, pp. 207-208.

Drolet R, Arendt TD, Stowe CM. (1984) Cacao bean shell poisoning in a dog. JAVMA 1984; 185(8): 902.

Entwistle, P. F. (1972): Pests of Cocoa. Longman Tropical Science Series, London, UK

Guinée, J. B., Gorrée, M., Heijungs, R., Huppes, G., Kleijn, R. (2001): Life Cycle Assessment: Operational Guide to the ISO Standards. Kluwer Academic Publishers. The Netherlands.

Hauschild, M., Wenzel, H (1998). Environmental assessment of products. Volume 2: Scientific background. London, UK, Chapman \& Hall.

Heijungs, R. (1992) (editor): Environmental Life Cycle Assessment of Products - Guide. Center for Environmental Science, University of Leiden, The Netherlands.

ICCO, 2010: ICCO Quarterly Bulletin of Cocoa Statistics, Vol. XXXVI, No. 4, Cocoa year 2009/2010. Published: 30-11-2010 (www.icco.org)

ICCO, 2007, Progress Report Action Programme on Pesticides, ICCO Executive Committee 133rd Meeting, EBRD Offices, London, 5-7 June, 2007

ISO 14040 (1997): Environmental management - Life cycle assessment - Principles and framework. International Organization for Standardization; Technical Committee ISO/TC 207/SC5.

ISO 14041 (1998): Environmental management - Life cycle assessment - Goal and scope definition and inventory analysis. International Organization for Standardization; Technical Committee ISO/TC 207/SC5.

ISO 14042 (2000a): Environmental management - Life cycle assessment - Life cycle impact assessment. International Organization for Standardization; Technical Committee ISO/TC 207/SC5.

ISO 14043 (2000b): Environmental management - Life cycle assessment - Life cycle interpretation. International Organization for Standardization; Technical Committee ISO/TC 207/SC5.

Johnson, E. S.; Aime, M.C.; Crozier, J.; Flood J.; Iwaro, D.A.; and Schnell, R.J.: A new morpho-type of Phytophthora palmivora on cacao in Central America, under IPMAdvances in Conventional Methods, in Proceedings of the $5^{\text {th }}$ INCOPED International Seminar on Cocoa Pests and Diseases, Akrofi, A.Y., Baah, F.(Eds) INCOPED Secretariat, Cocoa Research Institute, Tafo, Ghana 
Mahot, H.; Babin, R.; Dibog, L.; Tondje, P.R.; and Bilong, C. (2005): Biocontrol of cocoa mirid Sahlbergella singularis hagl. (Hemiptera: Miridae) with Beauveria bassiana Vuillemin: First results of activities carried out at IRAD, Cameroon in Proceedings of the $5^{\text {th }}$ INCOPED International Seminar on Cocoa Pests and Diseases, Akrofi, A.Y., Baah, F.(Eds) INCOPED Secretariat, Cocoa Research Institute, Tafo, Ghana

Moy, G.G.; Wessel, J.R. (2000): Codex Standard for Pesticides Residues, in Internatioanl Standards for Food Safety, Rees, N.; Watson, D., (Eds) Aspen Publishers Inc. Gaithersburg, MD, USA

Mannion, A.M., Bowlby, S.R (1992): Environmental Issues in the 90s, John Wiley \& Sons, Chichester

Ntiamoah, A., Afrane, G. Life Cycle Assessment of Chocolate produced in Ghana, in Appropriate Technologies for Environmental Protection in the Developing World. Yanful, Ernest K. (Editor) (2009), Springer. ISBN: 978-1- 40209138-4. Pp.35 - 41.

Offei, S.K.; Cornelius, E.W.; Sakyi-Dawson, O.(2008): Crop Diseases in Ghana and their Management, Sponsored by TALIF for College of Agriculture, University of Ghana, Legon, Accra, Smartline Ltd, ISBN 9988600275

Opoku, I.Y., Akrofi, A.Y., Appiah, A.A.(2007): Assessment of sanitation and fungicide application directed at cocoa tree trunks for the control of Phytophthora black pod infections in pods growing in the canopy, Eur J Plant Pathol (2007) 117:167-175

Opoku, I.Y., Gyasi, E. K., Onyinah, G. K., Opoku, E., Fofie, T.: The National Cocoa Diseases and Pests Control (CODAPEC)

Owusu-Manu, E. (1977) Insecticide residues and tainting in cocoa, Pesticide Management and Insecticide Resistance, 1977, Academic Press Inc, London

Opoku, I.Y.; Gyasi, E.K.; Onyinah, G.K.; Opoku, E. and Fofie, T (2006).: The National Cocoa Diseases and Pests Control(CODAPEC) Programme: Achievements and Challenges. Proceedings of the 15th International Cocoa Research Conference. San Jose, Costa Rica. 9 - 14 th October, 2006. Pp. 1007 - 1013.

Owusu-Manu, E.. Mirid (Capsid) Control - where do we stand? CRIG Newsletter Vol. 3 No. 4 October - December 2008. ISSN 0855-7918.

Pretty, J. N and Conway, G. R., 1988b, The Blue-Baby Syndrome and Nitrogen Fertilisers: A High Risk in the Tropics? International Institute for Environment and Development.

Rankin, CW; Nriagu, JO; Aggarwal, JK; Arowolo, TA; Adebayo, K; Flegal, AR (2005): Lead contamination in cocoa and cocoa products: isotopic evidence of global contamination. Environmental Health Perspectives 113 (10): 1344-1348.

Reuters (2007), New Benefits Found in Chocolate (www.NewsMax.com) Wires, Monday, Feb. 19, 2007 www.dropdata.org/cocoa/index.htm (The World's Worst Cocoa Problems, March 2011) www.chocolate.gourmetreceipe.com (Chocolate and its effect on health, March 2011)

UNDP, 1991, United Nations Environmental Programme, Environmental Data Report, 1991/1992, Third Edition, Nairobi, Kenya. 


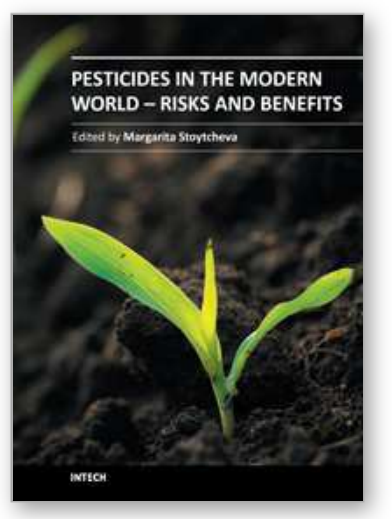

\author{
Pesticides in the Modern World - Risks and Benefits \\ Edited by Dr. Margarita Stoytcheva
}

ISBN 978-953-307-458-0

Hard cover, 560 pages

Publisher InTech

Published online 03, October, 2011

Published in print edition October, 2011

This book is a compilation of 29 chapters focused on: pesticides and food production, environmental effects of pesticides, and pesticides mobility, transport and fate. The first book section addresses the benefits of the pest control for crop protection and food supply increasing, and the associated risks of food contamination. The second book section is dedicated to the effects of pesticides on the non-target organisms and the environment such as: effects involving pollinators, effects on nutrient cycling in ecosystems, effects on soil erosion, structure and fertility, effects on water quality, and pesticides resistance development. The third book section furnishes numerous data contributing to the better understanding of the pesticides mobility, transport and fate. The addressed in this book issues should attract the public concern to support rational decisions to pesticides use.

\title{
How to reference
}

In order to correctly reference this scholarly work, feel free to copy and paste the following:

George Afrane and Augustine Ntiamoah (2011). Use of Pesticides in the Cocoa Industry and Their Impact on the Environment and the Food Chain, Pesticides in the Modern World - Risks and Benefits, Dr. Margarita Stoytcheva (Ed.), ISBN: 978-953-307-458-0, InTech, Available from:

$\mathrm{http}: / / w w w . i n t e c h o p e n . c o m / b o o k s / p e s t i c i d e s-i n-t h e-m o d e r n-w o r l d-r i s k s-a n d-b e n e f i t s / u s e-o f-p e s t i c i d e s-i n-t h e-$ cocoa-industry-and-their-impact-on-the-environment-and-the-food-chain

\section{INTECH}

open science | open minds

\author{
InTech Europe \\ University Campus STeP Ri \\ Slavka Krautzeka 83/A \\ 51000 Rijeka, Croatia \\ Phone: +385 (51) 770447 \\ Fax: +385 (51) 686166 \\ www.intechopen.com
}

\author{
InTech China \\ Unit 405, Office Block, Hotel Equatorial Shanghai \\ No.65, Yan An Road (West), Shanghai, 200040, China \\ 中国上海市延安西路65号上海国际贵都大饭店办公楼 405 单元 \\ Phone: +86-21-62489820 \\ Fax: +86-21-62489821
}


(C) 2011 The Author(s). Licensee IntechOpen. This is an open access article distributed under the terms of the Creative Commons Attribution 3.0 License, which permits unrestricted use, distribution, and reproduction in any medium, provided the original work is properly cited. 